\title{
THE ESSENCE OF PROPER SELECTION OF GAUSSIAN FILTRATION PARAMETERS
}

\author{
ISTOTA DOBORU ODPOWIEDNICH PARAMETRÓW \\ FILTRACJI GAUSSA
}

\author{
Aneta ŁETOCHA $^{1}$, Tatiana MILLER ${ }^{1}$
}

\begin{abstract}
Gaussian filter is currently included in all programs which analyze measured data. This type of filtration is commonly used around the world. ISO standard series about Gaussian filtering were published - especially ISO 4288 - therefore it is well described and known, but still exist threat, that it could be inadequately use by untrained personnel from industry and laboratories. Improper usage of Gaussian filtration can completely deform surface image and understate (most often) or overstate calculated parameters. The purpose of this paper is to show effects of improper application of the Gaussian filtration. Remind rules of selection Gaussian filter parameters and derogation of those rules. Measurements were performed with use contact profilometer TOPO 02, equipped with diamond stylus probe. Tip of the probe was cone-shaped with 60 degrees angle and radius equal $2 \mu \mathrm{m}$. Surfaces after grinding, eroding and milling were measured. Gaussian filtration with different cut-off wavelengths: $0,25 \mu \mathrm{m}, 0,8 \mu \mathrm{m}$ and $2,5 \mu \mathrm{m}$ was applied. Chosen height roughness profile parameters were calculated. Roughness profile graph and areal material ratio curve were analyzed.
\end{abstract}

Keywords: Gaussian filtration, Gaussian filter parameters, profilometer

Streszczenie: Filtr Gaussa jest powszechnie stosowany na całym świecie i zawarty we wszystkich programach analizujących zmierzone dane. Opublikowano serię norm ISO dotyczącą filtracji Gaussa (jedna z ważniejszych - ISO 4288), dlatego jest ona dobrze scharakteryzowana, ale w dalszym ciągu istnieje obawa, że może być stosowana w nieodpowiedni sposób przez personel laboratoryjny oraz związany $\mathrm{z}$ przemysłem. Niewłaściwe użycie filtracji Gaussa może całkowicie zniekształcić obraz zmierzonej powierzchni oraz zaniżyć (najczęściej) lub zawyżyć wartości obliczanych parametrów chropowatości. Celem tego referatu jest przedstawienie efektów niewłaściwego zastosowania filtracji Gaussa, przypomnienie zasad doboru parametrów filtru Gaussa, a także pokazanie odstępstw od tych wytycznych. Pomiary przeprowadzono z użyciem stykowego profilometru TOPO 02, wyposażonego w diamentową końcówkę pomiarową. Wykorzystano końcówkę

\footnotetext{
${ }^{1}$ The Institute of Advanced Manufacturing Technology, 30-011 Kraków, Wrocławska 37a, Poland
} 
pomiarową w kształcie stożka o kącie wierzchołkowym $-60^{\circ}$ oraz promieniu równym $2 \mu \mathrm{m}$. Zmierzono powierzchnie po: szlifowaniu, elektroerozji oraz frezowaniu. Zastosowano filtr Gaussa $\mathrm{z}$ następującymi długościami fali cut-off: $0,25 \mu \mathrm{m}, 0,8 \mu \mathrm{m}$ oraz $2,5 \mu \mathrm{m}$. Obliczono wybrane wysokościowe parametry profilu chropowatości. Analizie poddano wykres profilu chropowatości oraz krzywą przestrzennego udziału materiałowego.

Słowa kluczowe: filtracja Gaussa, parametry filtru Gaussa, profilometr

\section{INTRODUCTION}

Gaussian filter is currently included in all programs which analyze measured data. This type of filtration is commonly used around the world. ISO standard series about Gaussian filtering were published - especially ISO 4288 - therefore it is well described and known, but still exist threat, that it could be inadequately use by untrained personnel from industry and laboratories. Improper usage of Gaussian filtration can completely deform surface image and understate (most often) or overstate calculated parameters. The purpose of this paper is to show effects of improper application of the Gaussian filtration. Remind rules of selection Gaussian filter parameters and derogation of those rules.

\section{GAUSSIAN FILTER}

\subsection{STANDARDS}

First ISO standard related Gaussian filtration, ISO 11562 "Geometrical Product Specifications (GPS) - Surface texture: Profile method - Metrological characteristics of phase correct filters", was published in 1996. This standard gave information about phase correct filters - to which was included Gaussian filter. ISO 11562 describes: transmission characteristics of shortwave components and longwave components, weighting function, value of cut-off wavelength. It also shows the criteria of phase correct filter selection. PN-EN ISO 11562 was published in 1998 [1].

In 2011 new ISO standard was published, ISO 16610-21 "Geometrical product specifications (GPS) - Filtration - Part 21: Linear profile filters: Gaussian filters”, and replaced ISO 11562. This standard was one of many projects describing recently available filtration methods. Information contained in previous standard were maintained and supplemented. In new standard information about Gaussian filter are given separately for open profiles which we get during surface profile measurements and for closed profiles which we get after roundness measurements. Open and closed profiles are shown in the picture 1. This standard also give short information about very important for Gaussian (and not only) filtration problem, which are end effects. It invokes on ISO 16610-28 published in 2010, where we can find more information on this subject. PN-EN ISO 16610-21 was published in 2013 in English language and this year in Polish [2]. 

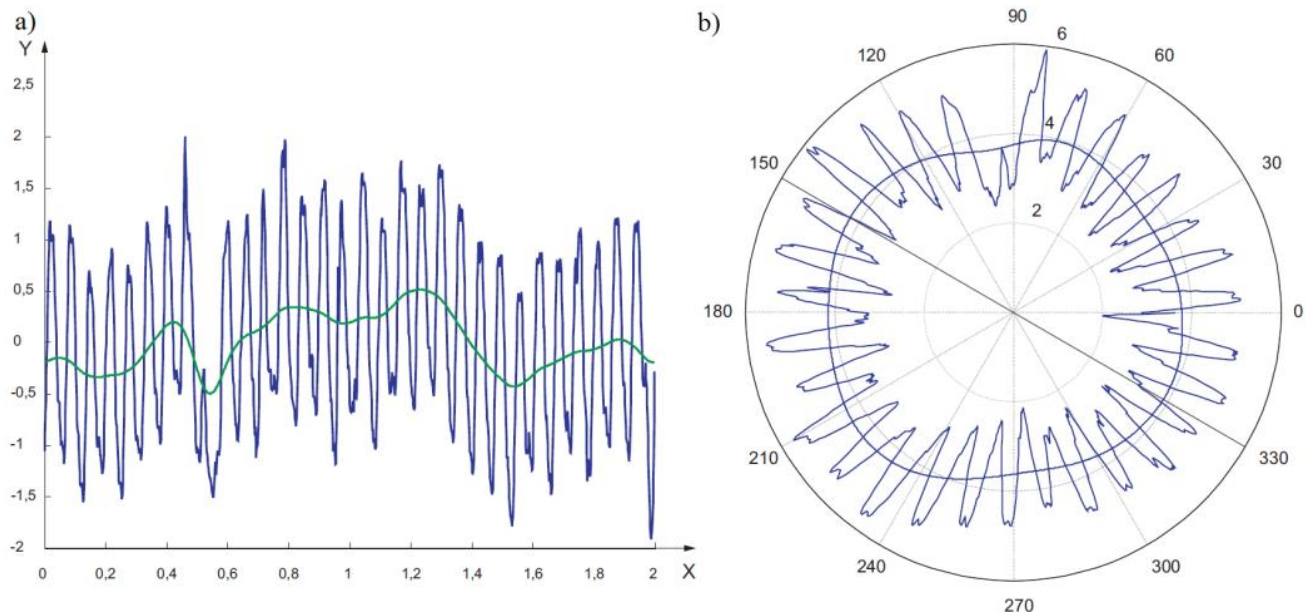

Figure 1. Examples: a) open profile, b) closed profile [2]

ISO 16610-28 presents few methods which help to avoid the end effects problem. For example by: zero padding, linear extrapolation, symmetric extension [3].

\subsection{CHARACTERISATION}

Gaussian filtration is currently one of best-described, best-defined, and most often used input data processing algorithm. It results i.a. from the fact, that Gauss filter is characterized by relatively easy calculating and interpretation method and the fact that all digital devices are equipped with the filter in their input data processing programs [2,3,5-7].

Gaussian filter is based on Fourier transform. During processing of Gaussian filter, used sampling interval is consistent with Nyquist theorem, what means that specifying sampling interval does not let to lose data. This filter type is characterized by weighting function. Weighting function of Gaussian filter for open profile is shown in Equation 1 [2].

$$
s(x)=\frac{1}{\alpha \times \lambda_{c}} \times \exp \left[-\pi\left(\frac{x}{\alpha \times \lambda_{c}}\right)^{2}\right]
$$

where:

$\mathrm{x}$ - the distance from the center (maximum) of the weighting function, $\lambda \mathrm{c}-$ the cut-off wavelength, $\alpha$ - a constant, to provide $50 \%$ transmission characteristic at the cut-off $\lambda c$ (is approximately 0,4697 ).

Second important thing related with Gaussian filter is transmission characteristic. Long wave components transmission characteristic is determined on the basis of Fourier transform of weighting function (Equation 2 [2]). Short wave components transmission characteristic (Equation 3 [2]) is its compliment. 


$$
\frac{a_{1}}{a_{0}}=\exp \left[-\pi\left(\frac{\alpha \times \lambda_{c}}{\lambda}\right)^{2}\right]
$$

where:

$\mathrm{a}_{0}$ - amplitude of a sinusoidal wave profile before filtering, $\mathrm{a}_{1}$ - amplitude of this profile in the mean line, $\lambda$ - is the wavelength of this sinusoidal profile.

$$
\frac{a_{2}}{a_{0}}=1-\exp \left[\left(\frac{\alpha \times \lambda_{c}}{\lambda}\right)^{2}\right] \quad \frac{a_{2}}{a_{0}}=1-\frac{a_{1}}{a_{0}}
$$

where:

$\mathrm{a}_{2}$ - amplitude of the short wave component of a sinusoidal wave profile, $\mathrm{a}_{0}$ - amplitude of a sinusoidal wave profile before filtering, $a_{1}$ - amplitude of this profile in the mean line, $\lambda$ - is the wavelength of this sinusoidal profile.

Gaussian filter is defined by cut-off wavelength value. Nowadays is commonly used in surface geometry structure researches and in the industry. The cut-off value decides about which frequency components will be transmitted, and which blocked. Depending on the roughness interval and profile character (periodicity) ISO standard for the Gaussian filters [4] determines suitable cut-off value. Parameters: Ra, Rz and $\mathrm{Sm}$ should be checked. Details presented in tables below.

Table 1. Cut-off wavelength selection and measuring distance depending

\begin{tabular}{|c|c|c|c|c|}
\hline \multicolumn{3}{|c|}{$\mathrm{Ra}[\mu \mathrm{m}]$} & $\begin{array}{l}\text { Roughness elementary } \\
\text { distance } l c \text { (cut-off) }\end{array}$ & $\begin{array}{c}\text { Roughness measuring } \\
\text { distance } l c[\mathrm{~mm}]\end{array}$ \\
\hline$(0,006)$ & $<\mathrm{R}_{\mathrm{a}} \leq$ & 0.02 & 0.08 & 0.4 \\
\hline 0.02 & $<\mathrm{R}_{\mathrm{a}} \leq$ & 0.1 & 0.25 & 1.25 \\
\hline 0.1 & $<\mathrm{R}_{\mathrm{a}} \leq$ & 2 & 0.8 & 4 \\
\hline 2 & $<\mathrm{R}_{\mathrm{a}} \leq$ & 10 & 2.5 & 12.5 \\
\hline 10 & $<\mathrm{R}_{\mathrm{a}} \leq$ & 80 & 8 & 40 \\
\hline
\end{tabular}
on the Ra parameter value for non-periodic profiles [4]

Table 2. Cut-off wavelength selection and measuring distance depending on the $\mathrm{Rz}$ parameter value for non-periodic profiles [4]

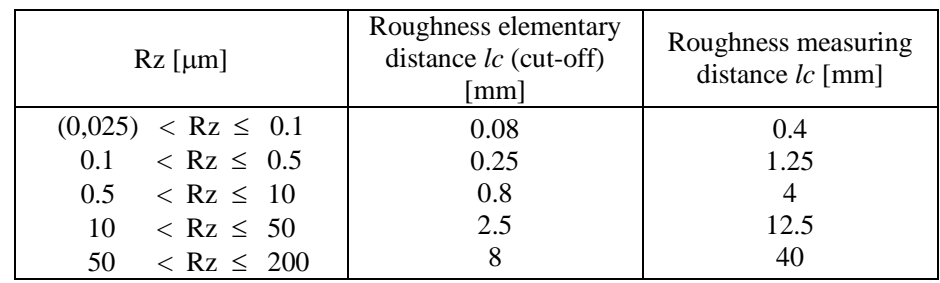


Table 3. Cut-off wavelength selection and measuring distance depending on the Sm parameter value for periodic profiles [4]

\begin{tabular}{|c|c|c|c|c|}
\hline \multicolumn{3}{|c|}{$\mathrm{Sm}[\mathrm{mm}]$} & $\begin{array}{l}\text { Roughness elementary } \\
\text { distance } l c \text { (cut-off) }\end{array}$ & $\begin{array}{l}\text { Roughness measuring } \\
\text { distance } l c\end{array}$ \\
\hline 0.013 & $<\mathrm{S}_{\mathrm{m}} \leq$ & 0.04 & 0.08 & 0.4 \\
\hline 0.04 & $<S_{m} \leq$ & 0.13 & 0.25 & 1.25 \\
\hline 0.13 & $<\mathrm{S}_{\mathrm{m}} \leq$ & 0.4 & 0.8 & 4 \\
\hline 0.4 & $<\mathrm{S}_{\mathrm{m}} \leq$ & 1.3 & 2.5 & 12.5 \\
\hline 1.3 & $<\mathrm{S}_{\mathrm{m}} \leq$ & 4 & 8 & 40 \\
\hline
\end{tabular}

\section{THE RESEARCH}

Measurements were performed with use contact profilometer TOPO 02 - produced by The Institute of Advanced Manufacturing Technology, equipped with inductive, diamond stylus probe. Tip of the probe was cone-shaped with 60 degrees angle and radius equal $2 \mu \mathrm{m}$ [8]. In research were used three samples, with surfaces after: eroding, grinding and milling (Figure 2).
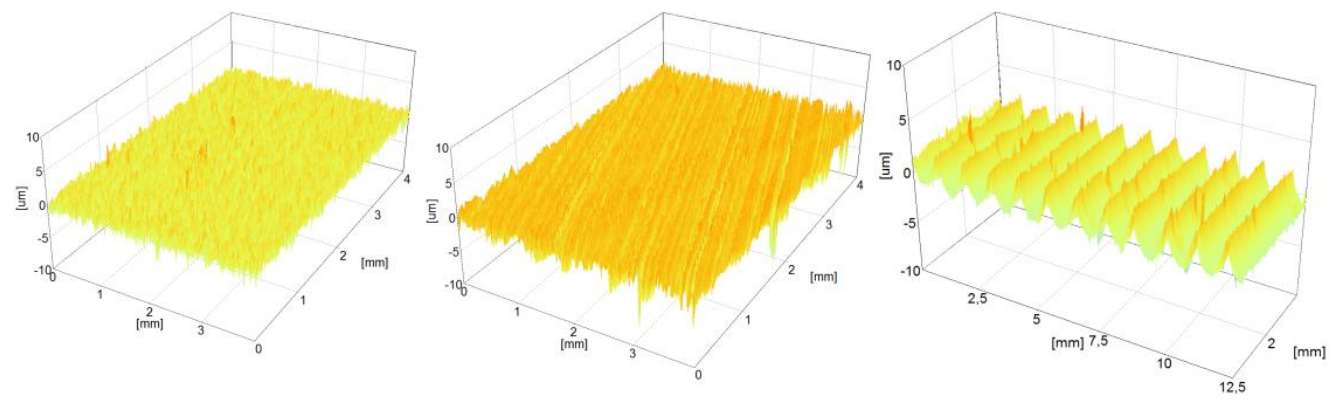

Figure 2. Measured surfaces, from the left: eroded, ground and milled

Measurements were performed on areas: 4 x $4 \mathrm{~mm}, 12,5 \times 4 \mathrm{~mm}$. Sampling interval in $Y$ axis was equal $20 \mu \mathrm{m}$, in $\mathrm{X}$ axis $0,2 \mu \mathrm{m}$ (for $4 \mathrm{~mm}$ distance) and 0,5 $\mu \mathrm{m}$ (for 12,5 $\mathrm{mm}$ distance). Measurement analysis were performed with use TOPOGRAFIA software (IAMT), which takes into account the recommendations from ISO 16610-28, to eliminate the influence of end effects on Gaussian filtered profile or surface. Gaussian filtration with different cut-off wavelengths: $0,25 \mu \mathrm{m}, 0,8 \mu \mathrm{m}, 2,5 \mu \mathrm{m}$ was applied. Height surface roughness parameter $\mathrm{Sz}$ was calculated. Statistical analysis of profile roughness parameters were calculated: Ra, Rz, $\mathrm{Rp}, \mathrm{Rv}, \mathrm{Rk}, \mathrm{Rpk}, \mathrm{Rvk}$. Roughness profile graph and areal material ratio curve were analyzed.

\section{RESULTS AND DISCUSSION}

Table 4 presents the results of profile roughness parameters calculated for eroded sample. It shows mean, max and min values for three cut-off values of Gaussian filter. Cut-off value designated by the ISO standard is marked by grey color in the table. Proper cut-off value selected based on results analysis (parameter values and profile graph) is bolded. Figure 3 
presents graph with mean values of calculated profile roughness parameters with use different cut-off values of Gaussian filter, for eroded sample.

Table 4. The results of profile roughness parameters of eroded surface after filtration with different cut-off values of Gaussian filter

\begin{tabular}{|c|c|c|c|c|c|c|c|c|c|}
\cline { 2 - 11 } \multicolumn{1}{c|}{} & \multicolumn{3}{c}{ Mean } & \multicolumn{3}{c|}{ Max } & \multicolumn{3}{c|}{ Min } \\
\hline $\begin{array}{c}\text { Cut-off } \\
\text { value } \\
{[\mathrm{mm}]}\end{array}$ & 0,25 & $\mathbf{0 , 8}$ & 2,5 & 0,25 & $\mathbf{0 , 8}$ & 2,5 & 0,25 & $\mathbf{0 , 8}$ & 2,5 \\
\hline $\mathrm{Ra}[\mu \mathrm{m}]$ & 0,480 & $\mathbf{0 , 5 7 8}$ & 0,614 & 0,581 & $\mathbf{0 , 7 1 3}$ & 0,750 & 0,398 & $\mathbf{0 , 4 7 8}$ & 0,507 \\
\hline $\operatorname{Rz}[\mu \mathrm{m}]$ & 3,199 & $\mathbf{3 , 6 9 9}$ & 3,860 & 5,026 & $\mathbf{5 , 4 2 7}$ & 5,426 & 2,461 & $\mathbf{2 , 9 6 7}$ & 3,096 \\
\hline $\operatorname{Rp}[\mu \mathrm{m}]$ & 1,274 & $\mathbf{1 , 4 9 2}$ & 1,570 & 2,321 & $\mathbf{2 , 3 6 2}$ & 2,440 & 0,968 & $\mathbf{1 , 1 6 5}$ & 1,197 \\
\hline $\operatorname{Rv}[\mu \mathrm{m}]$ & 1,925 & $\mathbf{2 , 2 0 7}$ & 2,290 & 2,943 & $\mathbf{3 , 0 6 9}$ & 3,253 & 1,403 & $\mathbf{1 , 6 1 4}$ & 1,703 \\
\hline $\operatorname{Rk}[\mu \mathrm{m}]$ & 1,459 & $\mathbf{1 , 7 8 1}$ & 1,891 & 1,720 & $\mathbf{2 , 2 1 8}$ & 2,380 & 1,141 & $\mathbf{1 , 4 1 8}$ & 1,499 \\
\hline $\operatorname{Rpk}[\mu \mathrm{m}]$ & 0,435 & $\mathbf{0 , 5 2 5}$ & 0,582 & 1,320 & $\mathbf{1 , 2 9 6}$ & 1,401 & 0,239 & $\mathbf{0 , 2 8 4}$ & 0,323 \\
\hline $\operatorname{Rvk}[\mu \mathrm{m}]$ & 0,836 & $\mathbf{0 , 9 8 0}$ & 1,024 & 1,455 & $\mathbf{1 , 9 6 6}$ & 2,100 & 0,542 & $\mathbf{0 , 6 8 0}$ & 0,668 \\
\hline
\end{tabular}

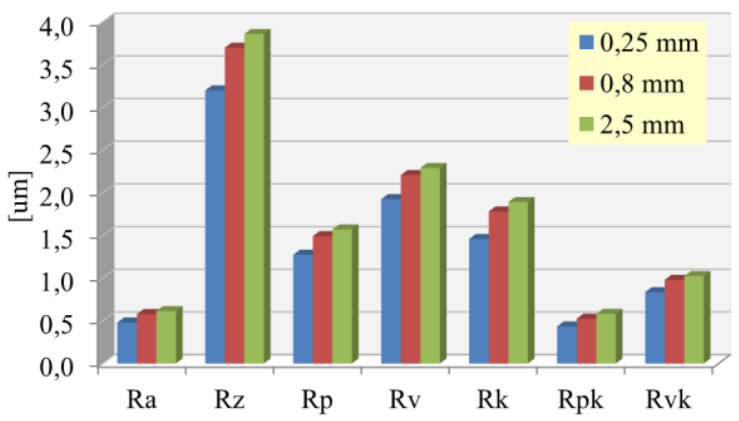

Figure 3. Mean values of profile roughness parameters of eroded surface after filtration with different cut-off values of Gaussian filter

We can notice how much profile roughness parameters are understated when we use improper (to small) cut-off value. The less sensitive is Ra parameter. Difference between $0,25 \mathrm{~mm}$ cutoff and $0,8 \mathrm{~mm}$ cut-off results is very significant. Disparity between $0,8 \mathrm{~mm}$ and $2,5 \mathrm{~mm}$ is relatively smaller. For this example cut-off value given by ISO standard is equal to the proper value founded based on the roughness profile graph.

Table 5 presents the results of profile roughness parameters calculated for ground sample. It shows mean, max and min values for three cut-off values of Gaussian filter. Cut-off value designated by the ISO standard is marked by grey color in the table. Proper cut-off value selected based on results analysis (parameter values and profile graph) is bolded. Figure 4 presents graph with mean values of calculated profile roughness parameters with use different cut-off values of Gaussian filter, for ground sample. 
Table 5. The results of profile roughness parameters of ground surface after filtration with different cut-off values of Gaussian filter

\begin{tabular}{|c|c|c|c|c|c|c|c|c|c|}
\cline { 2 - 10 } \multicolumn{1}{c|}{} & \multicolumn{4}{c}{ Mean } & \multicolumn{3}{c|}{ Max } & \multicolumn{3}{c|}{ Min } \\
\hline $\begin{array}{c}\text { Cut-off } \\
\text { value }[\mathrm{mm}]\end{array}$ & 0,25 & $\mathbf{0 , 8}$ & 2,5 & 0,25 & $\mathbf{0 , 8}$ & 2,5 & 0,25 & $\mathbf{0 , 8}$ & 2,5 \\
\hline $\operatorname{Ra}[\mu \mathrm{m}]$ & 0,740 & $\mathbf{0 , 8 5 6}$ & 0,897 & 0,846 & $\mathbf{1 , 0 1 5}$ & 1,052 & 0,674 & $\mathbf{0 , 7 8 0}$ & 0,810 \\
\hline $\operatorname{Rz}[\mu \mathrm{m}]$ & 4,915 & $\mathbf{5 , 3 3 6}$ & 5,491 & 7,648 & $\mathbf{8 , 1 1 5}$ & 8,469 & 4,021 & $\mathbf{4 , 3 9 3}$ & 4,523 \\
\hline $\operatorname{Rp}[\mu \mathrm{m}]$ & 1,769 & $\mathbf{1 , 7 4 9}$ & 1,758 & 2,213 & $\mathbf{2 , 2 1 0}$ & 2,331 & 1,511 & $\mathbf{1 , 5 0 5}$ & 1,546 \\
\hline $\operatorname{Rv}[\mu \mathrm{m}]$ & 3,147 & $\mathbf{3 , 5 8 7}$ & 3,732 & 5,435 & $\mathbf{6 , 2 3 4}$ & 6,547 & 2,373 & $\mathbf{2 , 7 4 3}$ & 2,755 \\
\hline $\operatorname{Rk}[\mu \mathrm{m}]$ & 2,202 & $\mathbf{2 , 5 2 1}$ & 2,638 & 2,604 & $\mathbf{2 , 8 3 6}$ & 3,095 & 1,907 & $\mathbf{2 , 1 1 2}$ & 2,231 \\
\hline $\operatorname{Rpk}[\mu \mathrm{m}]$ & 0,543 & $\mathbf{0 , 3 9 0}$ & 0,343 & 1,207 & $\mathbf{1 , 0 1 8}$ & 1,361 & 0,304 & $\mathbf{0 , 1 4 1}$ & 0,141 \\
\hline $\operatorname{Rvk}[\mu \mathrm{m}]$ & 1,352 & $\mathbf{1 , 5 9 8}$ & 1,710 & 1,984 & $\mathbf{2 , 8 1 2}$ & 3,143 & 0,925 & $\mathbf{1 , 1 0 4}$ & 1,225 \\
\hline
\end{tabular}

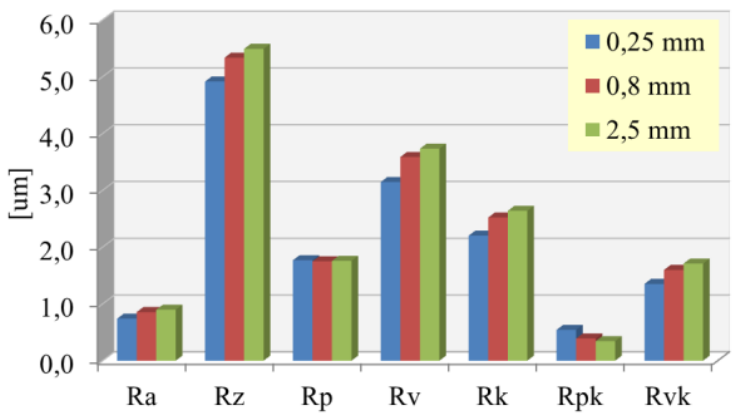

Figure 4. Mean values of profile roughness parameters of ground surface after filtration with different cut-off values of Gaussian filter

In this case situation is similar as for eroded surface. The bigger is difference between $0,25 \mathrm{~mm}$ cut-off and $0,8 \mathrm{~mm}$ cut-off. We can notice that Rp parameter have similar results for every cut-off value.

Table 6 presents the results of profile roughness parameters calculated for milled sample. It shows mean, max and min values for three cut-off values of Gaussian filter. Cut-off value designated by the ISO standard is marked by grey color in the table. Proper cut-off value selected based on results analysis (parameter values and profile graph) is bolded. Figure 5 presents graph with mean values of calculated profile roughness parameters with use different cut-off values of Gaussian filter, for ground sample.

Figure 6 presents graphs of primary, waviness and roughness profiles of eroded sample, after Gaussian filtration with different cut-off values. Figure 7 presents areal material ratio curves of eroded sample, after Gaussian filtration with different cut-off values. Graphs are cut from the top and bottom, to better see the differences between each result (the same in Figure 9 and Figure 11). 
Table 6 . The results of profile roughness parameters of milled surface after filtration with different cut-off values of Gaussian filter

\begin{tabular}{|c|c|c|c|c|c|c|c|c|c|}
\cline { 2 - 10 } \multicolumn{1}{c|}{} & \multicolumn{3}{c}{ Mean } & \multicolumn{3}{c|}{ Max } & \multicolumn{3}{c|}{ Min } \\
\hline $\begin{array}{c}\text { Cut-off } \\
\text { value } \\
{[\mathrm{mm}]}\end{array}$ & 0,25 & 0,8 & $\mathbf{2 , 5}$ & 0,25 & 0,8 & $\mathbf{2 , 5}$ & 0,25 & 0,8 & $\mathbf{2 , 5}$ \\
\hline $\operatorname{Ra}[\mu \mathrm{m}]$ & 0,077 & 0,309 & $\mathbf{0 , 8 5 3}$ & 0,212 & 0,487 & $\mathbf{1 , 0 3 4}$ & 0,056 & 0,281 & $\mathbf{0 , 7 9 1}$ \\
\hline $\operatorname{Rz}[\mu \mathrm{m}]$ & 1,035 & 2,124 & $\mathbf{3 , 8 9 9}$ & 2,696 & 3,696 & $\mathbf{5 , 7 3 1}$ & 0,639 & 1,687 & $\mathbf{3 , 3 9 0}$ \\
\hline $\operatorname{Rp}[\mu \mathrm{m}]$ & 0,493 & 1,308 & $\mathbf{2 , 3 5 7}$ & 1,350 & 1,937 & $\mathbf{3 , 0 6 6}$ & 0,374 & 1,177 & $\mathbf{2 , 1 7 3}$ \\
\hline $\operatorname{Rv}[\mu \mathrm{m}]$ & 0,543 & 0,816 & $\mathbf{1 , 5 4 2}$ & 1,346 & 1,855 & $\mathbf{2 , 6 6 5}$ & 0,250 & 0,474 & $\mathbf{1 , 2 1 1}$ \\
\hline $\operatorname{Rk}[\mu \mathrm{m}]$ & 0,138 & 0,371 & $\mathbf{1 , 8 5 9}$ & 0,440 & 1,042 & $\mathbf{3 , 2 4 4}$ & 0,095 & 0,231 & $\mathbf{1 , 4 6 8}$ \\
\hline $\operatorname{Rpk}[\mu \mathrm{m}]$ & 0,258 & 1,008 & $\mathbf{1 , 6 2 8}$ & 0,540 & 1,228 & $\mathbf{1 , 9 8 6}$ & 0,210 & 0,876 & $\mathbf{1 , 1 3 4}$ \\
\hline $\operatorname{Rvk}[\mu \mathrm{m}]$ & 0,188 & 0,295 & $\mathbf{0 , 3 5 5}$ & 0,640 & 1,196 & $\mathbf{2 , 2 4 6}$ & 0,089 & 0,097 & $\mathbf{0 , 0 6 8}$ \\
\hline
\end{tabular}

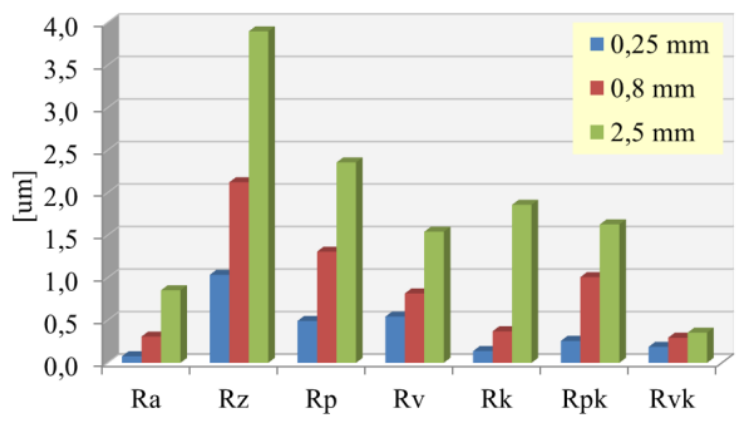

Figure 5. Mean values of profile roughness parameters of milled surface after filtration with different cut-off values of Gaussian filter

We can notice that for $0,25 \mathrm{~mm}$ cut-off value filter deletes not only waviness but also significantly disfigures the profile. Hills and dales of primary profile, which should be transmitted are too much cut. When we look at result after filtration with $2,5 \mathrm{~mm}$ cut-off value, we can see that not all waviness components are blocked by the filter and waviness profile look almost like horizontal line. In this case cut-off value of the Gaussian filter should be selected in accordance with ISO standard.

Figure 8 presents graphs of primary, waviness and roughness profiles of ground sample, after Gaussian filtration with different cut-off values. Figure 9 presents areal material ratio curves of ground sample, after Gaussian filtration with different cut-off values. This case is very similar to results from eroded sample and filtration parameters also should be chosen in accordance with ISO standard. 

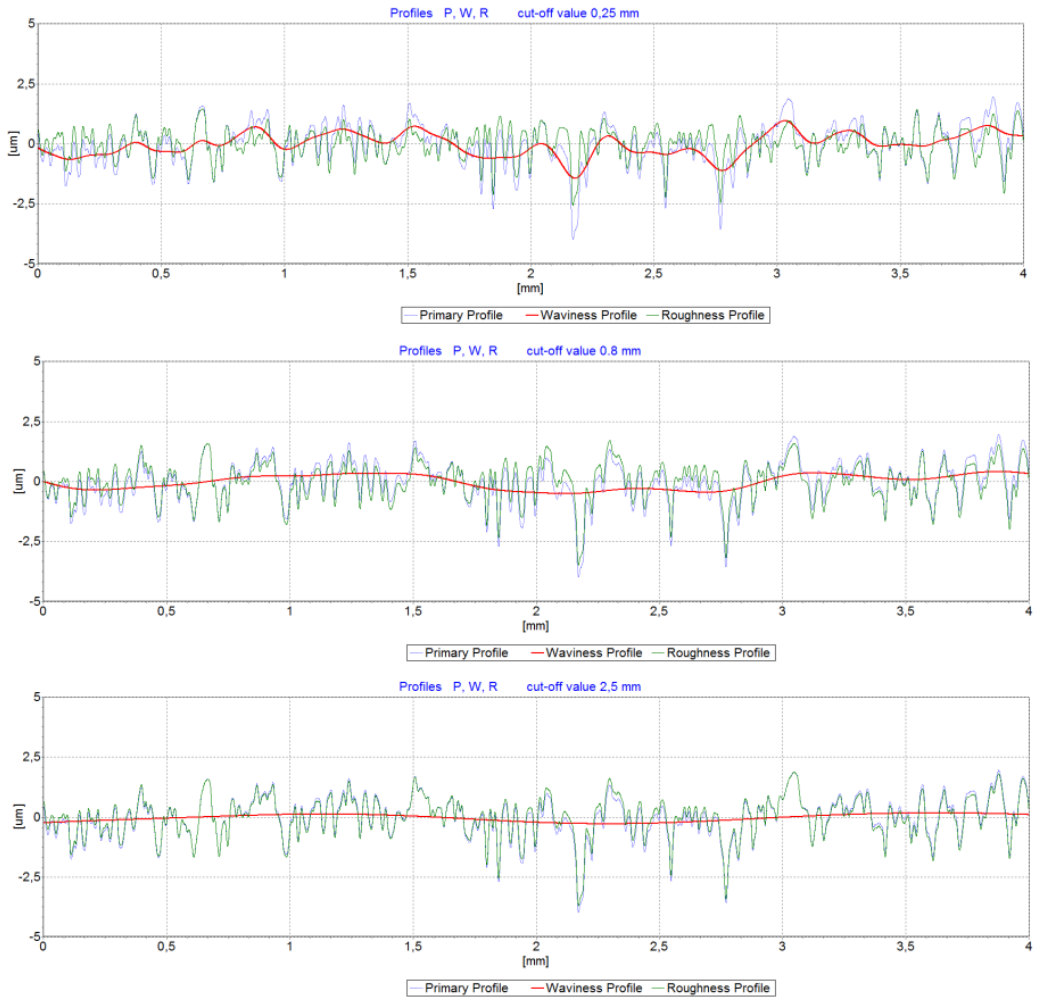

Figure 6. Graphs of eroded sample profiles after use different cut-off values of Gaussian filter

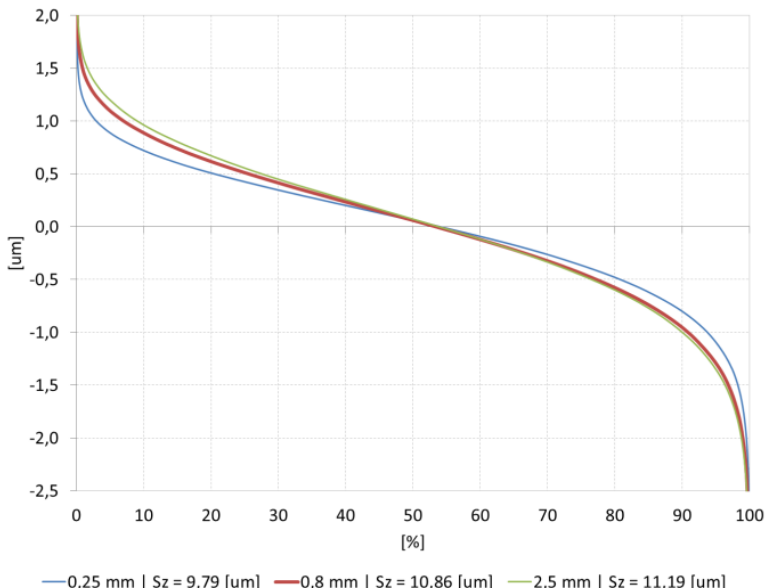

Figure 7. Areal material ratio curves of eroded sample after filtration with different cut-off values of Gaussian filter 

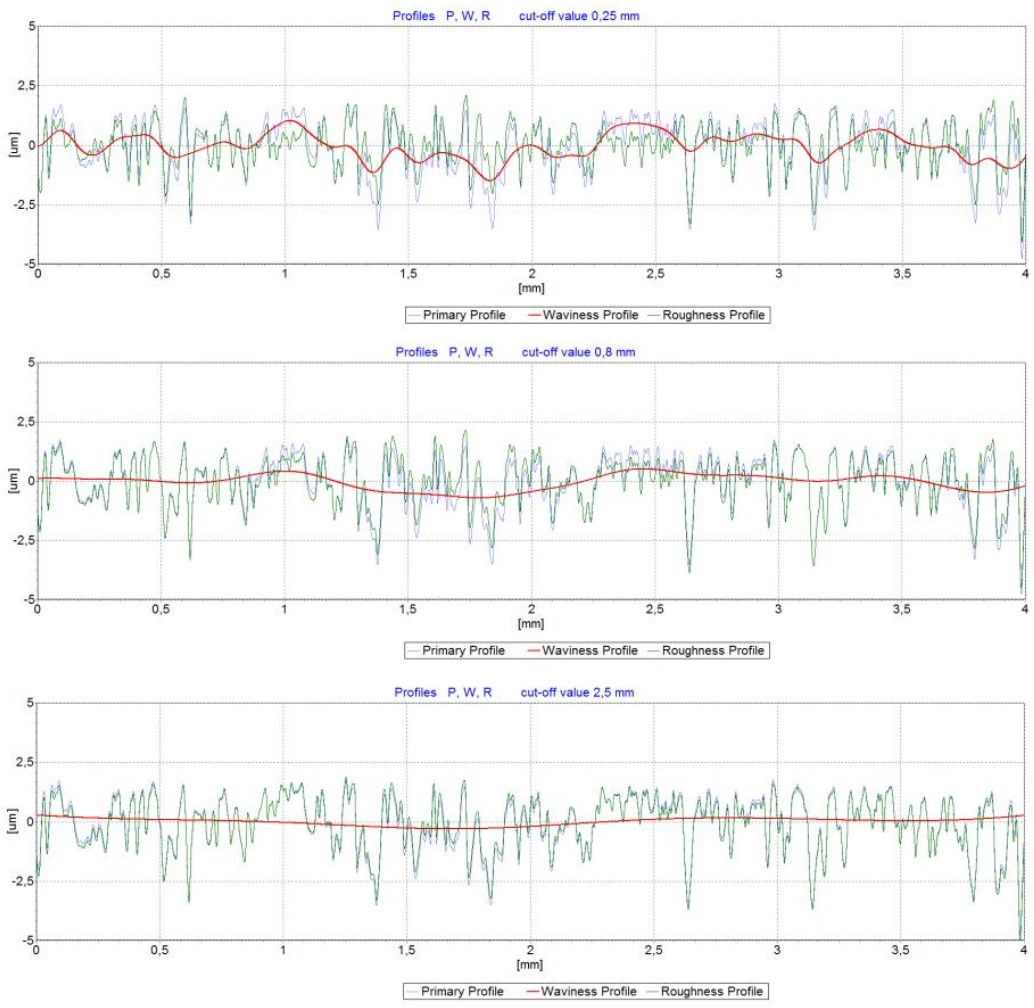

Figure 8. Graphs of ground sample profiles after use different cut-off values of Gaussian filter

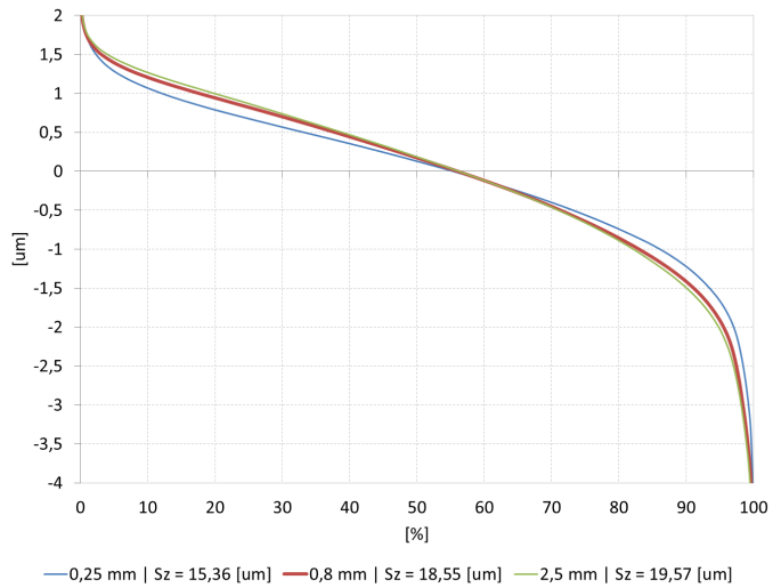

Figure 9. Areal material ratio curves of ground sample after filtration with different cut-off values of Gaussian filter 

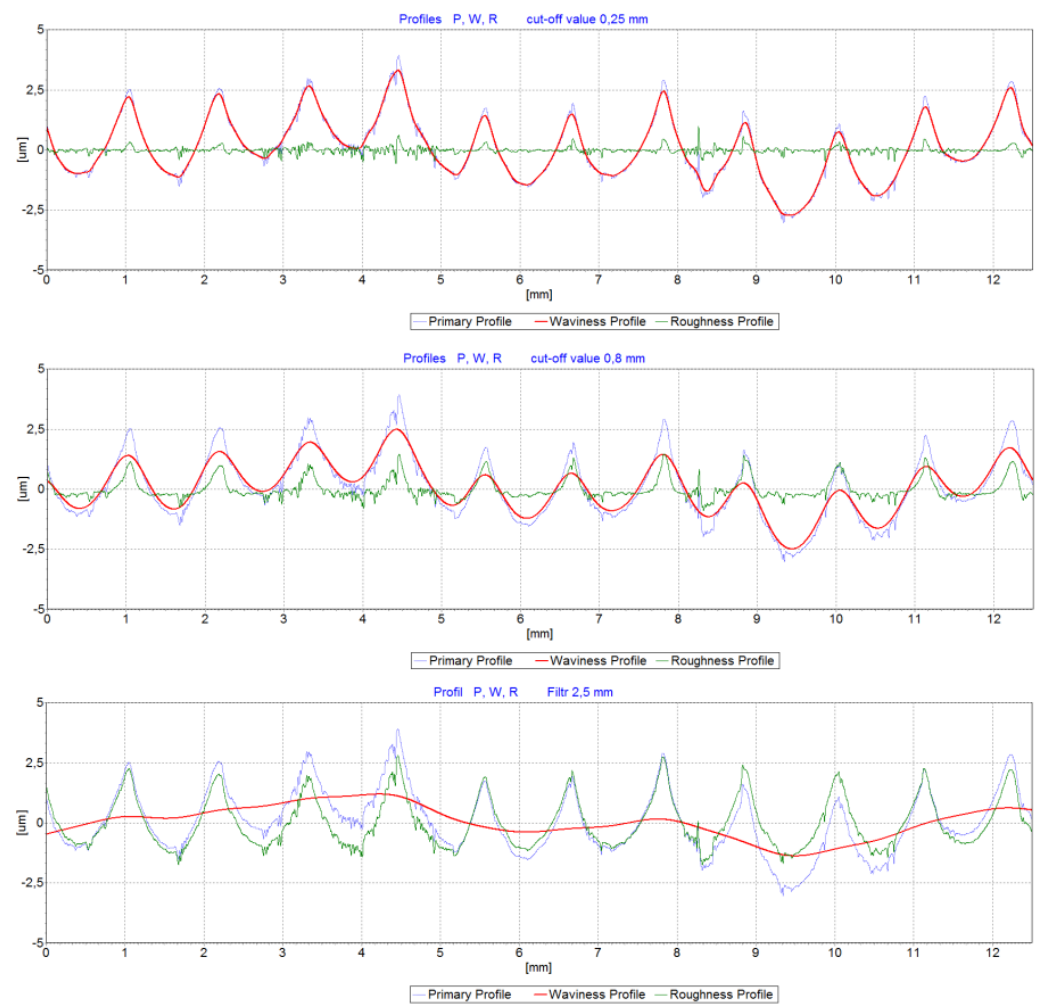

Figure 10. Graphs of milled sample profiles after use different cut-off values of Gaussian filter

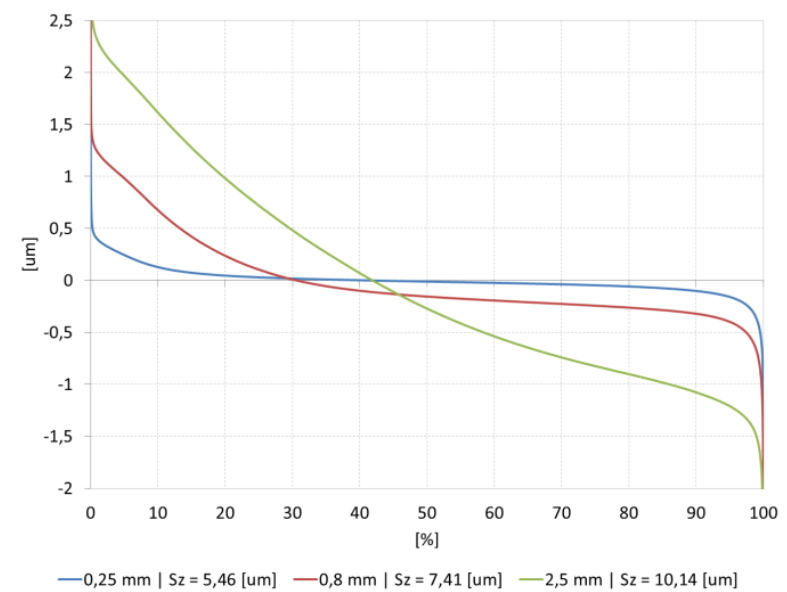

Figure 11. Areal material ratio curves of milled sample after filtration with different cut-off values of Gaussian filter 
Figure 10 presents graphs of primary, waviness and roughness profiles of milled sample, after Gaussian filtration with different cut-off values. Figure 11 presents areal material ratio curves of milled sample, after Gaussian filtration with different cut-off values. Results of this sample filtration are completely different than of previous samples. In this case the differences between each result are the most visible. For $0,25 \mathrm{~mm}$ cut-off we can see that tool trace is completely recognized as waviness components. If we take a look on the profile roughness parameters (Table 6.) we can see that the $\mathrm{Ra}$ and $\mathrm{Rz}$ values are in the range which indicates to use $0,8 \mathrm{~mm}$ cut-off. But we have to analyze also measurement graph. For $0,8 \mathrm{~mm}$ cut-off value part of the tool trace is transmitted, but still too much information is blocked. In this case the best to use is $2,5 \mathrm{~mm}$ cut-off value, because it blocks only the waviness components, not the important information.

\section{CONCLUSIONS}

The advantage of Gauss filter is sampling in accordance with Nyquist theorem which allows on filtered profile reconstruction. Negatives are: necessity of form deviations removal and end effects occurrence. Gauss filter is sensitive for slope and steeps.

During research it is very important to analyze not only roughness or waviness parameters and select proper filtration based on them, in accordance with ISO standard. Very often the most important information about cut-off selection we get from the measurement graphs. Recommendations in ISO standard are usually very useful, but there are cases when we have to ignore them.

If we are not sure to which cut-off value select - when we hesitate between two values, it is better to choose the bigger one, because then we are sure that will not lose important information and not to understate the results. Of course there are cases when, with this approach, waviness influence too much on roughness and overstate significantly the results, but it only proofs that the most important and the most useful is to carefully and precisely analyze the measurement graphs.

\section{LITERATURE}

[1] ISO 11562:1996, Geometrical Product Specifications (GPS) - Surface texture: Profile method - Metrological characteristics of phase correct filters.

[2] ISO 16610-21:2011, Geometrical product specifications (GPS) - Filtration - Part 21: Linear profile filters: Gaussian filters.

[3] ISO 16610-28:2010, Geometrical Product Specifications (GPS) - Filtration - Part 28: Profile filters: End effects.

[4] ISO 4288:1998, Geometrical Product Specification GPS - Surface texture: Profile method - Rules and procedures fort he assessment of surface texture.

[5] DOBRZAŃSKI P., PAWLUS P., Modification robust filtering of stratified surface topography, Metrology and Measurement Systems, Vol. XX, No. 1, 2013: 107-118.

[6] DOBRZAŃSKI P., PAWLUS P., Digital filtering of surface topography: Part I. Separation of one-process surface roughness and waviness by Gaussian convolution, Gaussian regression and spline filters, Precision Engineering 34, 2010: 647-650.

[7] ŁĘTOCHA A., MILlER T., Gaussian Filter and Morphological Filter - The Differences in Filtration Parameters Selection, International Journal of Mechanical Engineering and Automation, Vol. 1, No. 4, 2014 : 253-258.

[8] MILLER T., GAJDA K., ŁETOCHA A., Biuletyn Instytutu Zaawansowanych Technologii Wytwarzania Zakres zastosowania i możliwości pomiarowe modułowego systemu TOPO 02 do pomiaru $i$ analizy topografii powierzchni, Mechanik, 5-6, 2014: 424-427. 